\title{
OCTOBER 1975
}

FIFTEENTH YEAR - No. 175
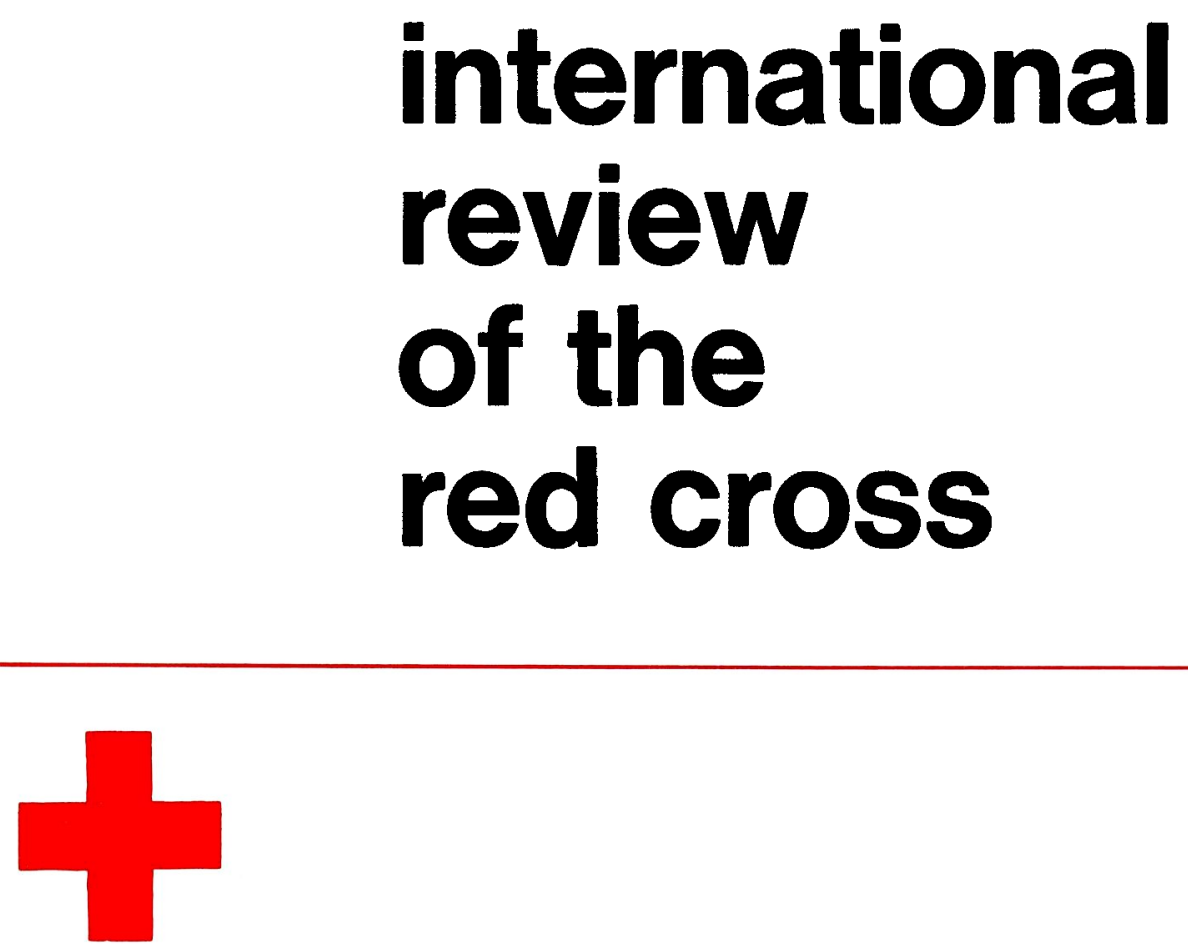

INTER ARMA CARITAS

GENEVA

INTERNATIONAL COMMITTEE OF THE RED CROSS FOUNDED IN 1863 


\section{INTERNATIONAL COMMITTEE OF THE RED CROSS}

Mr. ERIC MARTIN, Doctor of Medicine, Honorary Professor of the University of Geneva, President (member since 1973)

Mr. JEAN PICTET, Doctor of Laws, Chairman of the Legal Commission, Associate Professor at the University of Geneva, Vice-President (1967)

Mr. HARALD HUBER, Doctor of Laws, Federal Court Judge, Vice-President (1969)

Mr. HANS BACHMANN, Doctor of Laws, Director of Finance of Winterthur (1958)

Mrs. DENISE BINDSCHEDLER-ROBERT, Doctor of Laws, Professor at the Graduate Institute of International Studies, Geneva, Judge at the European Court of Human Rights (1967)

Mr. MARCEL A. NAVILLE, Master of Arts, ICRC President from 1969 to 1973 (1967)

Mr. JACQUES F. DE ROUGEMONT, Doctor of Medicine (1967)

Mr. ROGER GALLOPIN, Doctor of Laws, former ICRC Director-General (1967)

Mr. WALDEMAR JUCKER, Doctor of Laws, Secretary, Union syndicale suisse (1967)

Mr. VICTOR H. UMBRICHT, Doctor of Laws, Managing Director (1970)

Mr. PIERRE MICHELI, Bachelor of Laws, former Ambassador (1971)

Mr. GILBERT ETIENNE, Professor at the Graduate Institute of International Studies and at the Institut d'études du développement, Geneva (1973)

Mr. ULRICH MIDDENDORP, Doctor of Medicine, head of surgical department of the Cantonal Hospital, Winterthur (1973)

Mrs. MARION BOVÉE-ROTHENBACH, Master of Social Work (University of Michigan), Reader at the Ecole des Sciences sociales et politiques of the University of Lausanne (1973)

Mr. HANS PETER TSCHUDI, Doctor of Laws, former Swiss Federal Councillor (1973)

Mr. HENRY HUGUENIN, Bank Manager (1974)

Mr. GOTTFRIED DE SMIT, Managing Director (1974)

Mr. JAKOB BURCKHARDT, Doctor of Laws, Minister Plenipotentiary, Chairman of the Council of Federal Polytechnic Schools (1975)

Mr. THOMAS FLEINER, Master of Laws, Professor at the University of Fribourg (1975)

Mr. ALEXANDRE HAY, Lawyer, Director-General of the Swiss National Bank (1975)

Honorary members: Mr. JACQUES CHENEVIÈRE, Honorary Vice-President;

Miss LUCIE ODIER, Honorary Vice-President; Messrs. GUILLAUME BORDIER, PAUL CARRY, Mrs. MARGUERITE GAUTIER-VAN BERCHEM,

Messrs. ADOLPHE GRAEDEL, EDOUARD DE HALLER, RODOLFO OLGIATI, MAX PETITPIERRE, PAUL RUEGGER, DIETRICH SCHINDLER, FRÉDÉRIC SIORDET, ALFREDO VANNOTTI.

\section{EXECUTIVE BOARD}

Mr. ROGER GALLOPIN, President

Mr. VICTOR H. UMBRICHT, Vice-President

Mrs. DENISE BINDSCHEDLER-ROBERT

Mr. GILBERT ETIENNE

Dr. ULRICH MIDDENDORP

Mr. JEAN PICTET

Mr. GOTTFRIED DE SMIT

Mr. PIERRE MICHELI, Deputy member 


\section{INTERNATIONAL REVIEW OF THE RED CROSS}

OCTOBER 1975 - No. 175

\section{INTERNATIONAL COMMITTEE OF THE RED CROSS}

\section{IN THE RED CROSS WORLD}

MISCELLANEOUS

BOOKS AND REVIEWS
Gilbert Etienne : Action in Angola . . . . . . . 495

Tenth Anniversary of Henry Dunant Institute . . 499

External activities:

Africa-Latin America-Asia-Middle East . . 521

School textbook and soldier's manual . . . . . 527

Re-appraisal of the Role of the Red Cross . . . 529

Annual report of the League . . . . . . . . . 533

Canada . . . . . . . . . . . . 534

Indonesia . . . . . . . . . . 535

Japan . . . . . . . . . . . . . 535

Portugal . . . . . . . . . . 536

Henry Dunant Society . . . . . . . . . . . . 538

The problems of elderly people . . . . . . . . 539 


\section{FRENCH EDITION OF THE REVIEW}

\section{EXTRACTS FROM} THE REVIEW

SPANISH

\section{GERMAN}

INTERNATIONAL
The French edition of this Review is issued every month under the title of Revue internationale de la Croix-Rouge. It is, in principle, identical with the English edition and may be obtained under the same conditions.

E. Martin: El Presidente del Comité Internacional de la Cruz Roja y las Sociedades Nacionales - Actividades del CICR en 1974 - La Cruz Roja y el peligro de la Comercialización de productos sanguíneos.

Tätigkeit des IKRK im Jahre 1974 - Staatliche Unabhängigkeit und Familienzusammenführung.

The International Review is published each month by the International Committee of the Red Cross

17, avenue de la Paix, 1211 Geneva, Switzerland Postal Cheque No. 12 - 1767.

Annual subscription: Sw. Fr. 30.- (\$10.-)

Single copy Sw. Fr. 3.- $(\$ 1,-)$

EDITOR: J.-G. LOSSIER

The International Committee of the Red Cross assumes responsibility only for material over its own signature. 